\title{
Author Correction: Selection of reference genes for microRNA analysis associated to early stress response to handling and confinement in Salmo salar
}

Eduardo Zavala ${ }^{1}$, Daniela Reyes $^{1}$, Robert Deerenberg ${ }^{2}$ \& Rodrigo Vidal ${ }^{1}$

Correction to: Scientific Reports https://doi.org/10.1038/s41598-017-01970-3, published online 11 May 2017

In this Article, the legend of Figure 2 is incorrect:

"Correlation among geNorm (M value) and normFinder (stability value) results considering the pooled dataset." should read:

"Plasma cortisol levels ( \pm SEM) after stress experiment. *Statistical difference with respect to control $(\mathrm{p}<0.05)$."

In addition, the legend of Figure 3 is incorrect:

"Plasma cortisol levels ( \pm SEM) after stress experiment. *Statistical difference with respect to control $(\mathrm{p}<0.05)$."

should read:

"Correlation among geNorm (M value) and normFinder (stability value) results considering the pooled dataset."

(c) (i) Open Access This article is licensed under a Creative Commons Attribution 4.0 International License, which permits use, sharing, adaptation, distribution and reproduction in any medium or format, as long as you give appropriate credit to the original author(s) and the source, provide a link to the Creative Commons license, and indicate if changes were made. The images or other third party material in this article are included in the article's Creative Commons license, unless indicated otherwise in a credit line to the material. If material is not included in the article's Creative Commons license and your intended use is not permitted by statutory regulation or exceeds the permitted use, you will need to obtain permission directly from the copyright holder. To view a copy of this license, visit http://creativecommons.org/licenses/by/4.0/.

(C) The Author(s) 2018

\footnotetext{
${ }^{1}$ Department of Biology, Universidad de Santiago de Chile. Av. Libertador Bernardo O'Higgins, 3363, Santiago, Chile. ${ }^{2}$ Marine Harvest, camino el Tepual 8, Puerto Montt, Chile. Correspondence and requests for materials should be addressed to R.V. (email: ruben.vidal@usach.cl)
} 